\title{
Business Life Cycle and Capital Structure: Evidence from Chinese Manufacturing Firms
}

\author{
Lin Tian, Liang Han, Song Zhang*
}

\begin{abstract}
This paper uses a panel data-fixed effect approach and data collected from Chinese public manufacturing firms between 1999 and 2011 to investigate the impacts of business life cycle stages on capital structure. We find that cash flow patterns capture more information on business life cycle stages than firm age and have a stronger impact on capital structure decision-making. We also find that the adjustment speed of capital structure varies significantly across life cycle stages and that non-sequential transitions over life cycle stages play an important role in the determination of capital structure. Our study indicates that it is important that policy-makers ensure that product and financial markets are well-balanced.
\end{abstract}

Key words: capital structure, cash flow, life cycle, transition

JEL codes: M10, M21, M41

\section{Introduction}

In the published literature, various measures are used to characterize the stages of the business life cycle, including firm age, size, growth, strategies, flexibility and controllability (La Rocca et al., 2011). The classification of life cycle stages reflects the variation of business growth and the adaptability of businesses to the competitive environment (Bulan and Yan, 2009). Cash flow patterns have been identified as a valid measure of life cycle stages, and reflect the interaction among resource allocation, operating capacity and business strategies (Thanatawee, 2011). Measuring business life cycle using cash flow patterns enables us to capture non-sequential transition between stages which could not be measured by sequential proxies, such as firm age. Dickinson (2011) provides a detailed classification of business life cycle stages using cash flow patterns and demonstrates its reliability in predicting business performance.

There is considerable empirical evidence on the impacts of life cycle stages on various aspects of business behavior, performance and decision-making, such as foreign direct investment (Lin et al., 2012), demand on financial products (Berger and Udell, 1998), market selection (Bellone et al., 2008), cost of finance (Kim et al., 2012), strategy-making (Verreynne and Meyer, 2010), dividend policy (DeAngeloet al., 2006) and accounting practice (Kallunki and Silvola, 2008). Life cycle effects have also been found in the investigation of the impacts of financial performance on environmental policy (Elsayed and Paton, 2009), the impacts of ownership structure on corporate performance (Liang et al., 2011) and credit rating migration risks (Fei et al., 2012), but few have examined transitions in the business life cycle.

The present paper investigates the influence of business life cycle stages on capital structure, with life cycle stages measured by firm age and cash flow patterns. We find that cash flow patterns capture more information on the business life cycle and have a stronger impact on capital structure decision-making than firm age. We also find that the adjustment speed of capital structure varies significantly across life cycle stages and that non-sequential

*Lin Tian, PhD candidate, Surrey Business School, University of Surrey, Guildford, UK. Email: lin.tian@surrey.ac.uk; Liang Han (corresponding author), Professor, School of Economics and Management, Shihezi University, Shihezi, Xinjiang; Reader, Surrey Business School, University of Surrey, Guildford, Surrey, UK. Email: 1.han@surrey.ac.uk; Song Zhang, Lecturer, Lancashire Business School, University of Central Lancashire, Preston, UK. Email: szhang4@uclan.ac.uk. 
transition over life cycle stages plays an important role in the determination of capital structure. The present study contributes to the existing literature in the areas of the business life cycle and business finance in a number of ways. First, the current study provides clear evidence for Chinese public manufacturing companies that measuring the business life cycle using cash flow patterns sheds more light on capital structure decision-making than firm age. Our approach also captures the non-monotonic effects of life cycle stages on capital structure and such effects may not be available from empirical studies that use firm age (e.g. Dewaelheyns and Cynthia, 2010; Sakai et al., 2010). Second, we provide empirical evidence on the non-sequential transition of life cycle stages, with approximately 30 percent of our samples having moved back to an early stage of the business life cycle. This non-sequential transition is not captured by the traditional life cycle measures, such as firm age (see Pfaffermaye et al., 2013). We find that the transition also matters in capital structure decision-making. Third, compared with cross-sectional data analysis, we use empirical models to examine the dynamics of capital structure along the business life cycle and find a significant variation in the capital structure adjustment speeds in different life cycle stages.

The remainder of the paper is structured as follows. Section II reviews the existing literature on the business life cycle and its relationship with capital structure, and evaluates a new measure of the business life cycle proposed by Dickinson (2011): cash flow patterns. Section III introduces the data and variables and sets up the models for our empirical analysis. Section IV provides the descriptive statistics, documents the pattern of transition and presents the empirical results. Section V concludes and some policy implications are provided.

\section{Business Life Cycle and Its Relationship with Capital Structure}

\section{Business Life Cycle}

The business life cycle theories originated in the 1950s and have been developed further in the following decades (e.g. by Lippit and Schmidt, 1967; Adizes, 1979, 1996). It has been accepted in the literature that business characteristics, performance and behavior vary from one stage to another. During the birth stage of the business cycle, businesses are usually organized in a simple and informal structure and success in this stage is achieved through trial in generating distinctive competences and seeking a sustainable market niche to continue as a viable entity (Kallunki and Silvola, 2008). Firms at this stage usually have net cash outflows because they make investments to expand (Frielinghaus et al., 2005) and have relatively low profits (Marshall and Heffes, 2004). Therefore, young firms are often financed by equity capital to sustain their business, which also signals their high growth potential (Fluck, 2000).

The growth stage of the business cycle is characterized by rapid sales growth, product diversification and distinctive competences (Miller and Friesen, 1984). A functionally-based structure is established, middle-level managers play an important role in daily operations and procedures are formalized to ensure administrative efficiency (Adizes, 2004). Moreover, when businesses grow rapidly, they rely heavily on external financial markets to raise capital for investment and existing activities, and their demand for capital is greater than their ability to generate cash internally (Lemmon and Zender, 2010). Marketing

also plays a pronounced role, with extensive product ranges and limited decentralization of power making firms increasingly less sensitive to market changes (Frielinghaus et al., 2005). The growth stage ends as the growth of sales starts to slow down.

At the maturity stage of the business cycle, businesses are characterized by stabilized sales levels and falling innovation levels because of the high level of competition and market saturation (Miller and Friesen, 1984). Forming administrative objectives and developing the structure of the firm become more complicated as expanding product-market scope becomes a factor for firms (Adizes, 2004). The demand for capital reduces gradually and the internal cash flow generated from operations is able to meet the requirements of firms' development, 
although they are able to borrow more easily and at a lower cost (Bulan and Yan, 2009); therefore, firms in this stage prefer to use equity finance (Hamilton and Fox, 1998).

Long-term stability indicates the start of a decline stage for many businesses and revival occurs only among businesses that recognize and initiate drastic changes necessary to alter their current situation to cope with more complex and diversified markets (Miller and Friesen, 1984). With complex control and planning systems in place, firms are better able to diversify and innovate to achieve a turnaround or even new growth (Merchant, 1997). However, if firms fail to implement measures to improve growth, they enter the final stage of their life cycle, the decline stage, which is characterized by market stagnation, and declining sales and profitability. Firms in this stage are usually conservative in innovation and rapidly losing market shares, profitability and even retained earnings. When firms are moving into the stage of decline, they usually try to conserve resources and, therefore, abstain from innovation. They may also need to adjust their financing structure (e.g. recapitalization) when they have insufficient resources (Frielinghaus et al., 2005).

To capture the variation in business characteristics, performance and behavior, various proxies have been used in the published literature to classify business life cycle stages. The traditional measures of life cycle stages include firm age, size, growth potential and dividend policy, which are mainly sequential measures (Khan and Watts, 2009). The implicit assumption in using these measures is that a firm develops sequentially through its life cycle; these proxies ignore the fact that a firm life cycle can be cyclical in nature (Amit and Schoemaker, 1993). Many business growth models focusing on external dynamics and internal capacity changes assume that there are a limited number of distinct stages in the lifetime of a firm. Indeed, these business life cycle models have been criticized for their linear nature (e.g. Levie and Lichtenstein, 2010), and, hence, inapplicability to the real world; a number of transition frameworks have shown a growing diversity and heterogeneity of development processes (Levie and Lichtenstein, 2010). Dickinson (2011, p. 1974) argues that "a firm is a portfolio of multiple products, each potentially at a different product life cycle stage." Substantial product innovations, expansion into new markets and structural changes may cause non-sequential movement of a firm across its life cycle stages. The level of an organization's initial endowment may interact with its mortality rate (Jovanovic, 1982).

Dickinson (2011) proposes a non-sequential measure of life cycle stages: cash flow patterns. Compared with traditional life cycle proxies, the main benefit of the cash flow pattern proxy is that it reflects complete financial information rather than being a single indicator of firm-specific characteristics (e.g. age, size, sales growth, strategies, flexibility and controllability). Therefore, cash flow patterns are argued to be a better measure of life cycle stages as businesses may strive to maintain their optimum life cycle position and cash flow is better aligned with the functional form of business. Dickinson (2011) examines the possible outcomes of net operating, investing and financing cash flows, and divides business life cycle stages into birth, growth, mature, revival and decline (see Table 1). In earlier stages of the life cycle, net operating cash flows and net financing cash flows are positive, while net investing cash flows are negative for young firms as profit margins are maximized and firms are inclined to make early investments to deter competitors' entry into the market (Jovanovic, 1982). When businesses enter revival and decline stages, net operating cash flows and net financing cash flows decrease with the declining growth rates. Instead, net investing cash flows present a positive relationship with business development, because, in a revival or decline stage, a business usually intends to liquidate assets to support operations and reduce existing debts (Dickinson, 2011).

Table 1. Life Cycle Stages and Cash Flow Patterns

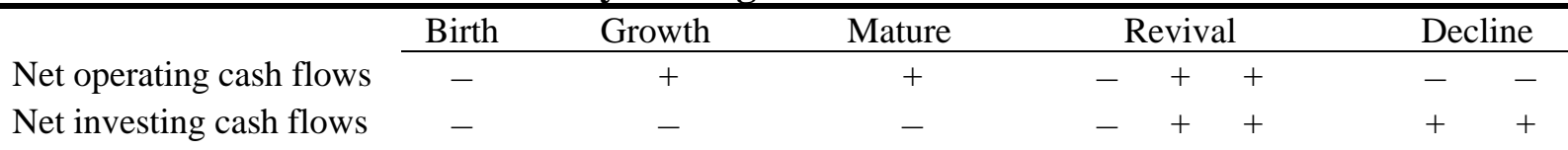


Source: Dickinson (2011, p. 1974).

Notes: "+" represents increasing cash flows and "-" represents decreasing cash flows. There is more than one possible cash flow change in revival and decline stages (see Dickinson (2011) for more detailed information).

Classifying and understanding life cycle stages is important for the strategic planning of business. Firms can adjust their management styles, organizational structures, communication and decision-making processes, and strategies according to the life cycle stage. Classifying business life cycle stages also offers management a guideline as to how business characteristics vary in different development stages and a diagnostic tool indicating how a business can reach and maintain growth. Understanding firm life cycle and growth patterns has multiple advantages: it not only provides management with a compass to guide firms' strategic direction, but also helps us to understand how the firm is financed over time (Black, 1998).

\section{Business Life Cycle and Capital Structure}

The firm life cycle is particularly pertinent to its financing decisions and firm characteristics in various life cycle stages are very important for making financing decisions (Adizes, 2004). Different financing decisions in different life cycle stages reflect the extent of investment requirements (Fama and French, 2005). Trade-off theory (Myers, 1984) suggests that capital structure decisions are based on balancing the benefits and costs of debt financing (Deloof and Overfelt, 2008), and that the benefits and costs vary significantly over life cycle stages. Bankruptcy costs are higher for firms in the birth and growth stages than those in the mature and revival stages, because in these stages firms are subjected to higher level of liquidity risks and asymmetric information issues. Trade-off theory also implies that in the revival and decline stages firms tend to experience a decline in earnings, which may lead to a decrease in the taxes paid by firms. As a result, firms might reduce their debt. Therefore, firms in birth and growth stages, and firms in revival and decline stages would have lower debt ratios than firms in the mature stage.

According to pecking order theory (Myers, 1984), the highly profitable firms with higher earnings would have less debt and firms in birth or decline stage would have higher debt ratios than firms in the growth and mature stages because of the lower earnings available from internal sources (Bulan and Yan, 2009). While in the mature stage, firms generate substantial retained earnings which might meet the demand of funds and, therefore, they may have less debt (Michaelaset al., 1999). Debt financing patterns over firm life cycle stages have been investigated from the perspective of business and financial risks, but not in view of earnings ability. It is found that with business and financial risks invariably decreasing and increasing over life cycle stages, firms should design their financial strategies to meet the various financial requirements over time (Bender and Ward, 1993).

Apart from different classification of firm life cycle stages, firm age has also been widely used in the empirical analysis of capital structure and considered as one of the most important determinants of capital structure. This is because: (i) firm age captures the stage of the business in the life cycle and reflects financing ability; and (ii) firm age has also been used as a valid and positive signal for creditworthiness, track record and information transparency when banks make lending decisions (La Rocca et al., 2011). Therefore, there is a positive relationship between debt ratio and firm age. However, it is also found that businesses in later life cycle stages, such as the mature and revival stages, retain more earnings and have lower demand for external debt finance, and they tend to have lower debt ratios (La Rocca et al., 2011).

In view of the forgoing, it is worth expecting that there would be a strong linkage between capital structure and business life cycle. To capture the dynamic effects, we choose 
how firms adjust the capital structure against their optimal leverage as the departure to make an empirical analysis on comparing the different effects of cash flow patterns and ages on firms' adjustment speed of capital structure, and further investigating the role played by transition between life cycle stages on capital structure decision-making.

\section{Data and Methodology}

To investigate the impacts of life cycle stages on capital structure, we collect firm-level information from the public manufacturing sector in China between 1999 and 2011. These firms are publicly listed on either the Shanghai or Shenzhen Stock Exchange (A-shares) and their firm-level information is collected from China Stock Market Accounting Research and China Securities Regulatory Commission. Our panel data also capture the dynamics of firmlevel characteristics. We use 1485 sample firms and 11581 firm-year observations in the empirical analysis.

Following Rajan and Zingales (1995), we use total debt ratio (Debtratio ${ }_{i, t}$ ) to measure the capital structure of a sample firm and we capture firm characteristics by size, profitability, tangibility, tax and growth potential. We use firm age to measure the life cycle stages, and follow Dickinson (2011) to categorize samples into birth, growth, maturity, revival and decline according to their cash flow patterns (see Table 1). Following Warr et al. (2012), we develop a model to capture the dynamics of capital structure of a sample firm, which may adjust its debt ratio to an optimal level over time as follows:

$$
\text { Debtratio }_{i, t}-\text { Debtratio }_{i,(t-1)}=\lambda \times\left(\text { Debtratio }_{i, t}{ }-\text { Debtratio }_{i,(t-1)}\right)+\varepsilon_{i, t} .
$$

Equation (1) could be written as:

$$
\text { Debtratio }_{i, t}=\lambda \times \text { Debtratio }_{i, t}^{*}+(1-\lambda) \times \text { Debtratio }_{i,(t-1)}+\varepsilon_{i, t},
$$

where Debtratio $_{i, t}$ and Debtratio $i(t-1)$ represent firm $i$ 's total debt ratio in year $t$ and $(t-1)$, respectively, and Debtratio ${ }_{i, t}$ is firm $i$ 's optimal total debt ratio in year $t$. $\varepsilon_{i, t}$ is the error term and $\lambda$ stands for the speed of adjustment with a value between 0 and $1 .{ }^{1}$ Following Fama and French (2002), we estimate the optimal debt ratio at time $t$ using a vector of firm characteristics at time $t-1$ and rewrite Equation (2) as:

$$
\text { Debtratio }_{i, t}=\alpha_{0}+(1-\lambda) \times \text { Debtratio }_{i,(t-1)}+\widehat{\beta} \times X_{i,(t-1)}^{\prime}+\mu_{i, t} \text {, }^{\prime}
$$

where $\alpha_{0}$ is the constant term, $X_{i,(t-1)}$ ' is a vector of firm level characteristics at $(t-1)$ and $u_{i, t}$ is the error term at time $t$. To consider the determinant effects of life cycle stages, we include a life cycle measure in the following empirical model as follows and the life cycle is measured by either firm age or stage based on cash flow patterns proposed by Dickinson (2011):

$$
\text { Debtratio }_{i, t}=\alpha_{0}+(1-\lambda) \times \text { Debtratio }_{i,(t-1)}+\widehat{\beta} \times X_{i,(t-1)}^{\prime}+\widehat{\delta} \times \text { life }_{\text {cycle }} \text { ch,t }_{i, t} \text {. }^{\prime}
$$

\footnotetext{
${ }^{1}$ The adjustment speed measures to what extent (in percentage) the gap between the actual debt ratio and the optimal debt ratio could be filled. It has been accepted that the speed is dependent on firm, industry, time and other economic factors (e.g. GDP growth).
} 
Equation (4) establishes the econometric framework for the empirical analysis presented in Section IV, which considers both the dynamics of capital structure decision-making and the business life cycle.

\section{Empirical Analysis}

\section{Descriptive Statistics and Life Cycle Transition}

Table 2 presents the definition of variables and their descriptive statistics. It shows that the sample firms have an average total debt ratio of 46 percent, ranging from 44 percent for firms in the mature stage to 53 percent for those in the decline stage. The U-shaped relation found between life cycle stages and capital structure is consistent with the pattern when firm age is considered (Pfaffermayr et al. 2013). This reflects the change of earnings ability of firms along their life cycle and the trade-off between external debt finance and internal finance. The analysis of variance (ANOVA) test suggests that there is a variation in capital structure among samples in different life cycle stages. Net profitability ranges from 1.28 percent for decline firms to 5.31 percent for growing firms, with an average of 4.76 percent for all firmyear observations. The variation in profitability implies that the life cycle stages classified by cash flow patterns reflect the earnings ability of a business along its life cycle and this is consistent with the predictability of business performance by cash flow patterns. Other determinants of capital structure, such as firm size, growth rate of assets, tangibility and tax payment, also show very clear patterns and variations in different life cycle stages classified by cash flow patterns. To avoid the bias that come from the high correlation among independent variables in the regression, Table 3 reports the simple continuous correlations of the independent variables and shows that none is larger than 0.30 , minimizing the issues of multicollinearity in the following multivariate analysis.

Table 2. Variable Definitions and Descriptive Statistics

\begin{tabular}{|c|c|c|c|c|c|c|c|c|}
\hline & & Pooled & Birth & Growth & Mature & Revival & Decline & $F$-test \\
\hline $\begin{array}{l}\text { Number of } \\
\text { observations }\end{array}$ & & 11581 & 1484 & 4686 & 4215 & 773 & 423 & \\
\hline $\begin{array}{l}\text { Percentage of total } \\
\text { samples }\end{array}$ & & 100.00 & 12.81 & 40.46 & 36.40 & 6.67 & 3.65 & \\
\hline Total debt ratio $(\%)$ & $\begin{array}{l}\text { Total liabilities/Total } \\
\text { assets } \times 100\end{array}$ & $\begin{array}{c}46.19 \\
(18.89)\end{array}$ & $\begin{array}{c}48.29 \\
(18.87)\end{array}$ & $\begin{array}{c}46.57 \\
(17.64)\end{array}$ & $\begin{array}{c}44.01 \\
(19.11)\end{array}$ & $\begin{array}{c}48.13 \\
(20.1515)\end{array}$ & $\begin{array}{c}52.75 \\
(22.33)\end{array}$ & $34.62 * * *$ \\
\hline Profitability (\%) & $\begin{array}{l}\text { Net income/Total assets } \times \\
100\end{array}$ & $\begin{array}{c}4.76 \\
(18.55)\end{array}$ & $\begin{array}{c}3.07 \\
(15.46)\end{array}$ & $\begin{array}{c}5.31 \\
(12.59)\end{array}$ & $\begin{array}{c}5.16 \\
(14.85)\end{array}$ & $\begin{array}{c}4.40 \\
(48.98)\end{array}$ & $\begin{array}{c}1.28 \\
(14.89)\end{array}$ & $8.43 * * *$ \\
\hline Size & $\begin{array}{l}\text { Natural log valueof total } \\
\text { assets }\end{array}$ & $\begin{array}{c}9.15 \\
(0.50)\end{array}$ & $\begin{array}{c}9.20 \\
(0.46)\end{array}$ & $\begin{array}{c}9.14 \\
(0.51)\end{array}$ & $\begin{array}{l}9.15 \\
(0.50)\end{array}$ & $\begin{array}{c}9.19 \\
(0.50)\end{array}$ & $\begin{array}{c}9.17 \\
(0.50)\end{array}$ & $4.69 * * *$ \\
\hline Growth $(\%)$ & $\begin{array}{l}\text { (Total assets }- \text { Opening } \\
\text { balance of total } \\
\text { assets)/Opening balance } \\
\text { of total assets } \times 100\end{array}$ & $\begin{array}{l}41.27 \\
(1620)\end{array}$ & $\begin{array}{c}38.41 \\
(65.24)\end{array}$ & $\begin{array}{l}75.09 \\
(2546)\end{array}$ & $\begin{array}{c}13.08 \\
(29.66)\end{array}$ & $\begin{array}{c}13.22 \\
(47.15)\end{array}$ & $\begin{array}{c}8.83 \\
(35.11)\end{array}$ & 0.93 \\
\hline Tangibility (\%) & $\begin{array}{l}\text { (Total fixed assets }+ \\
\text { Inventories)/Total assets } \\
\times 100\end{array}$ & $\begin{array}{c}0.85 \\
(3.98)\end{array}$ & $\begin{array}{c}0.87 \\
(3.23)\end{array}$ & $\begin{array}{c}0.93 \\
(5.20)\end{array}$ & $\begin{array}{c}0.74 \\
(2.22)\end{array}$ & $\begin{array}{c}1.02 \\
(4.77)\end{array}$ & $\begin{array}{c}0.64 \\
(2.50)\end{array}$ & 1.87 \\
\hline $\operatorname{Tax}(\%)$ & Tax/Total assets $\times 100$ & $\begin{array}{c}1.88 \\
(57.28)\end{array}$ & $\begin{array}{c}0.65 \\
(6.33)\end{array}$ & $\begin{array}{c}1.44 \\
(61.07)\end{array}$ & $\begin{array}{c}2.97 \\
(75.72)\end{array}$ & $\begin{array}{c}0.75 \\
(3.48)\end{array}$ & $\begin{array}{c}1.32 \\
(12.60)\end{array}$ & 0.59 \\
\hline Age & $\operatorname{Ln}(1+$ firm age $)$ & $\begin{array}{c}8.14 \\
(5.32)\end{array}$ & $\begin{array}{c}9.54 \\
(4.96)\end{array}$ & $\begin{array}{c}8.95 \\
(4.75)\end{array}$ & $\begin{array}{c}9.95 \\
(4.93)\end{array}$ & $\begin{array}{l}11.45 \\
(4.91)\end{array}$ & $\begin{array}{c}12.12 \\
(5.162)\end{array}$ & $74.48 * * *$ \\
\hline
\end{tabular}

Notes: Reported here are the mean values of variables, with standard deviations in parentheses. We report the ANOVA $F$-test results in the last column. Assets are measured by book value. ***** and* stand for statistical significance at 1,5 and 10-percent levels, respectively.

Table 3. Correlation Matrix

$\begin{array}{lllllll}1 & 2 & 3 & 4 & 5 & 6 & 7\end{array}$




\begin{tabular}{llccccccc}
\hline 1 & Debt ratio & 1.0000 & & & & & & \\
2 & Profitability & $-0.0858^{* * *}$ & 1.0000 & & & & & \\
3 & Size & $0.1407 * * *$ & $-0.0492^{* * *}$ & 1.0000 & & & & \\
4 & Tangibility & $-0.0287^{* * *}$ & $-0.0275^{* * *}$ & $-0.1454^{* * *}$ & 1.0000 & & & \\
5 & Growth & -0.0074 & 0.0031 & 0.0042 & -0.0015 & 1.0000 & & \\
6 & Tax & 0.0072 & 0.0039 & $-0.0733^{* * *}$ & $0.1844 * * *$ & -0.0010 & 1.0000 & \\
7 & Age & $0.1262 * * *$ & $-0.0666^{* * *}$ & $0.2559^{* * *}$ & $0.0290 * * *$ & $-0.0237 * *$ & $0.0249 * * *$ & 1.0000 \\
\hline
\end{tabular}

Note: $* * * * *$ and $*$ represent significance levels at 1,5 and 10 -percent, respectively.

As mentioned above, one of the advantages of Dickinson's (2011) approach to classifying business life cycle stages by cash flow patterns is that the transition of businesses through life cycle stages can be measured in a non-sequential way. Table 4 reports the patterns of transition of life cycle stages and we use three dummies to define the transition: rejuvenator $_{i, t}$, stayer $_{i, t}$ and developer ${ }_{i, t}$. For example, a sample firm is defined as a rejuvenator at year $t$ (rejuvenator ${ }_{i, t}=1$ ) if it was in a later stage in year $t-1$ and an earlier stage in year $t$. A sample firm is defined as a stayer in year $t\left(\right.$ stayer $\left._{i, t}=1\right)$ if it stayed in the same stage in both year $t-1$ and year $t$. A firm is defined as a developer (developer $i, t=1)$ if it was in an earlier stage in year $t-1$ and a later stage in year $t$. Table 4 shows that among all firm-year observations and in any 2 consecutive years, 29.30 percent of total samples experienced a rejuvenation process and moved back to an earlier stage of the life cycle; 42.18 percent of samples stayed in the same stage and 28.52 percent developed further into a later stage. The distribution of transitions varies across the life cycle stages: 77.59 percent of birth-staged firms are rejuvenators and 22.41 percent are stayers. However, it is not easy for firms at later stages in the cycle to be rejuvenated and only 10 percent of mature-staged firms are transited from later stages. Nearly half of the samples in a growth or a mature stage would stay in the same life cycle stage. This transition process through business life cycle stages is not easily captured by traditional life cycle measures; for example, firm age and the Pearson $\chi^{2}$ confirms the variation of distribution of transition. Non-sequential transition, such as rejuvenating, reflects the non-sequential change of cash patterns of the firms.

Table 4. Transition of Life Cycle Stages

\begin{tabular}{lccc}
\hline Stage & Rejuvenator (\%) & Stayer (\%) & Developer (\%) \\
\hline Pooled & 29.30 & 42.18 & 28.52 \\
Birth & 77.59 & 22.41 & - \\
Growth & 38.02 & 52.33 & 9.66 \\
Mature & 10.15 & 44.25 & 45.60 \\
Revival & 8.92 & 19.42 & 71.65 \\
Decline & - & 25.13 & 74.87 \\
\hline
\end{tabular}

\section{Empirical Results}

The objective of this research is to investigate the impacts of life cycle stages on capital structure. First, we regress capital structure, measured by the total debt ratio, on a group of lagged firm-level determinants and life cycle stages, where decline stage is used as a base group. Table 5 reports the results and Hausman tests support the fact that fixed effect estimation is more appropriate than the random effect approach for our samples. In Models 1 and 2, we use cash flow pattern classified life cycle stages and firm age, respectively, and the results show that firms in the birth stage have higher debt ratios and firms in the revival stage have lower debt ratios than the base group firms in a decline stage. This implies that firms in their early (mature) stage have weaker (stronger) ability to generate finance internally, via retained profit, and they can raise capital by borrowing more. 
Model 2 shows little evidence that firm age has any statistically significant impact on capital structure as a measure of life cycle. Therefore, a general pattern of debt ratio movement along the business life cycle is that the ratio decreases until a revival stage and then increases during the decline stage. Such a U-shaped pattern is consistent with the change in financial risk along the business life cycle where financial deficit increases and firms tend to have lower debt ratios when they develop (Bender and Ward, 1993).

Table 5. Determination of Capital Structure: Fixed Effect Estimation

\begin{tabular}{|c|c|c|c|}
\hline & Model 1 & Model 2 & Model 3 \\
\hline & 23.0644 & -23.1538 & -21.0874 \\
\hline Constant & $(4.9623)^{* * *}$ & $(5.2796)^{* * *}$ & $(4.9561)^{* * *}$ \\
\hline & 0.5291 & 0.5233 & 0.5282 \\
\hline Debt ratlo $i,(t-1)$ & $(0.0091)^{* * *}$ & $(0.0092) * * *$ & $(0.0091)^{* * *}$ \\
\hline & -0.0134 & -0.0128 & -0.0120 \\
\hline Profutabiluty $i,(t-1)$ & $(0.0049) * * *$ & $(0.0049) * * *$ & $(0.0049)^{* *}$ \\
\hline & 4.7020 & 3.9642 & 4.3736 \\
\hline Stze $_{i,(t-1)}$ & $(0.5455)^{* * *}$ & $(0.5574) * * *$ & $(0.5463) * * *$ \\
\hline & 0.0355 & 0.0256 & 0.0187 \\
\hline Ianglbillty $_{i,(t-1)}$ & $(0.0556)$ & $(0.0557)$ & $(0.0555)$ \\
\hline & -0.0002 & -0.0002 & -0.0002 \\
\hline Growth $_{i,(t-1)}$ & $(0.0001)^{* * *}$ & $(0.0001)^{* * *}$ & $(0.0001)^{* * *}$ \\
\hline $\operatorname{Tax}_{i,(t-1)}$ & $\begin{array}{l}-0.0030 \\
(0.0027)\end{array}$ & $\begin{array}{l}-0.0035 \\
(0.0027)\end{array}$ & $\begin{array}{l}-0.0027 \\
(0.0027)\end{array}$ \\
\hline Birth $_{i, t}$ & $\begin{array}{c}1.4408 \\
(0.5898)^{* *}\end{array}$ & & $\begin{array}{c}3.5800 \\
(0.6712)^{* * *}\end{array}$ \\
\hline Growth $_{i, t}$ & $\begin{array}{c}0.3561 \\
(0.5527)\end{array}$ & & $\begin{array}{c}1.8141 \\
(0.6002)^{* * *}\end{array}$ \\
\hline Mature $_{i, t}$ & $\begin{array}{l}-0.8904 \\
(0.5465)\end{array}$ & & $\begin{array}{l}-0.2714 \\
(0.5557)\end{array}$ \\
\hline Revival $_{i, t}$ & $\begin{array}{c}-1.9828 \\
(0.6104)^{* * *}\end{array}$ & & $\begin{array}{c}-1.7575 \\
(0.6095)^{* * *} *\end{array}$ \\
\hline Rejuvenator $_{i, t}$ & & & $\begin{array}{c}-1.4058 \\
(0.2653) * * *\end{array}$ \\
\hline Developer $_{i, t}$ & & & $\begin{array}{c}0.7804 \\
(0.2690)^{* * * *}\end{array}$ \\
\hline$A g e_{i, t}$ & & $\begin{array}{l}-1.7538 \\
(4.4536)\end{array}$ & \\
\hline $\operatorname{Age}^{2} i, t$ & & $\begin{array}{c}2.7980 \\
(1.8863)\end{array}$ & \\
\hline Year dummies & Yes & Yes & Yes \\
\hline Number of observations & 8842 & 8826 & 8842 \\
\hline$F$-test & $242.07 * * *$ & $260.98 * * *$ & $224.35 * * *$ \\
\hline Adjuated $R^{2}$ & 0.293 & 0.286 & 0.297 \\
\hline Hausman $C h i^{2}$ & $3486.58 * * *$ & $9759.54 * * *$ & $1784.59 * * *$ \\
\hline
\end{tabular}

Notes: According to Equation (4), the coefficient of Debtratio $i(t-1)$ is $(1-\lambda)$ and it is a measure of capital structure adjustment speed $\lambda$. Standard errors are reported in parentheses. ${ }^{* * *}, * *$ and $*$ represent the statistical significance levels of 1,5 and 10 percent, respectively.

In Model 3, we consider the transition of life cycle stages and include two dummy variables to investigate the impacts of rejuvenation and development in the life cycle on capital structure, where a dummy of "stayer" is used as the base group. Model 3 shows two important results. First, it reinforces the prior result that firms in earlier stages (birth and growth) have higher debt ratios and firms in the revival stage have lower debt ratios than firms in the decline stage. Second, it suggests that along with life cycle stages, the transition 
of stages also has a strong impact on capital structure where rejuvenators (developers) have lower (higher) debt ratios than those firms staying in the same life cycle stages.

Table 5 also suggests that less profitable, bigger firms and those with lower growth rates would have higher debt ratios. Tangibility and tax have little impact on debt ratios; this is probably because all sample firms are in the same manufacturing industry and their asset tangibility and taxation follow similar patterns. Furthermore, as defined in Equation (4), the coefficient of Debtratio $_{i,(t-1)}$ is $(1-\lambda)$ and it works as a measure of capital structure adjustment speed $(\lambda)$ in a dynamic setting. The adjustment speed is very stable over the three models, with values of $47.09(1-0.5291 \times 100), 47.67(1-0.5233 \times 100)$ and $47.18(1-$ $0.5282 \times 100)$ percent reflecting the strong robustness of the models. It implies that around 47 percent of the debt ratio gap between actual and optimal levels could be covered annually. ${ }^{2}$

The results in Table 5 suggest that firm age has little impact on capital structure. We further investigate whether firm age has any impact on capital structure within a specific life cycle stage and the results are reported in Table 6 . The results show that, first, the age effect on capital structure is statistically insignificant and, second, in a dynamic setting, capital structure adjustment speed $(\lambda)$ varies from one life cycle stage to another. The adjustment speed shows a U-shaped pattern which is similar to the pattern of debt ratio over the life cycle: it is 68.52 (birth), 61.31 (growth), 26.91 (mature), 42.96 (revival) and 48.78 (decline) percent, respectively (calculated by the $[1-$ coefficient of Debtratio $i,(t-1)]$ from Table 6 ). This confirms the strong impacts of cash flow patterns, as a life cycle measure, on capital structure and adjusting speed. Mature firms hold sufficient cash which is used to increase net working capital rather than to adjust capital structure (Byoun, 2008). Mature firms usually have lower growth rates than firms in a birth and growth stage, and they are less ready to adjust their capital structure than fast growing firms (Drobetz and Wanzenried, 2006).

Table 6. Determination of Capital Structure: Firm Age Effect within Life Cycle Stages

\begin{tabular}{lccccc}
\hline & Birth & Growth & Mature & Revival & Decline \\
\hline Constant & -27.8892 & -0.2072 & -3.4901 & -11.4399 & -31.4453 \\
& $(24.6939)$ & $(10.7519)$ & $(7.9644)$ & $(36.2926)$ & $(50.2547)$ \\
Debt ratio $i,(t-1)$ & 0.3148 & 0.3869 & 0.7309 & 0.5704 & 0.5122 \\
& $(0.0393)^{* * *}$ & $(0.0179)^{* * *}$ & $(0.0139)^{* * *}$ & $(0.0527)^{* * *}$ & $(0.0761)^{* * *}$ \\
Age ${ }_{i, t}$ & -11.9369 & -2.7786 & -1.6951 & -17.7179 & -21.4480 \\
& $(18.3054)$ & $(7.5867)$ & $(6.9098)$ & $(41.3929)$ & $(48.4635)$ \\
Age $_{i, t}$ & 6.5582 & 2.0144 & 1.9441 & 6.0144 & 14.7375 \\
Firm characteristics $_{i,(t-1)}$ & $(7.6627)$ & $(3.3229)$ & $(2.8748)$ & $(15.8028)$ & $(18.9524)$ \\
Year dummies & Yes & Yes & Yes & Yes & Yes \\
\hline Number of observations & 1169 & 3397 & 3263 & 637 & 360 \\
F-test & $12.38^{* * *}$ & $66.57^{* * *}$ & $156.45^{* * *}$ & $6.90^{* * *}$ & $4.35^{* * *}$ \\
Hausman $\chi^{2}$ & $179.27^{* * *}$ & $793.31^{* * *}$ & $353.39^{* * *}$ & $63.68^{* * *}$ & $60.82^{* * *}$ \\
\hline Notes: Accos
\end{tabular}

Notes: According to Equation (4), the coefficient of Debtratio $i_{i,(t-1)}$ is $(1-\lambda)$ and it is a measure of capital structure adjustment speed $\lambda$. Standard errors are reported in parentheses.***,** and* represent the statistical significance levels of 1, 5 and 10, respectively. Standard errors are reported in parentheses.

As shown in Table 5 (Model 3), transition of life cycle stage may affect the capital structure of business. The table also shows that rejuvenators have lower and developers have higher debt ratios than those firms staying in the same life cycle stage. To further investigate the impacts of transition, we use interaction terms to capture the effects within and across life

${ }^{2}$ The published empirical studies find that the speed varies over time: 18.5 percent from 1999 to 2004 in Qian et al. (2009), 35.7 percent from 1970 to 2007 in Hovakimian and Li (2011) and 17 percent from 1963 to 2001 in Huang and Ritter (2009). 
cycle stages; the results are reported in Table 7. We use "birth-stayer" (i.e. a firm staying in the birth stage in two consecutive time periods) as a base group and the coefficients reflect the impacts of transition-stage interaction terms on capital structure. The only difference between Models 1 and 2 is that Model 1 does not include firm age while Model 2 does. Both models generate consistent results (see Table 7) and show that each sub-group has a significantly negative coefficient, suggesting that birth-stayers (base group) have the highest debt ratio, consistent with the results in Table 5 (Models 1 and 3). The transition effect is more significant in growth and mature stages where the magnitude of the coefficient is greater for rejuvenators and smaller for developers than for stayers. In Figure 1 we plot the transition-stage effects on capital structure. The figure shows that base group birth-stayers have the highest debt ratio and all other sub-groups have lower debt ratios, which are only a proportion $(<100 \%)$ of that of the base group. In terms of the life cycle effects on capital structure, the figure shows a U-shape where firms in mature and revival stages have lower debt ratios and firms in birth, growth and decline stages have higher debt ratios. The figure also shows the transition effect on capital structure in the growth and mature stages. There are two important implications. First, the U-shape is consistent with the published literature (e.g. Myers, 1984; Michaelas et al., 1999; Bulan and Yan, 2009; Lemmon and Zender, 2010), showing a trade-off between the internally generated capital and the use of external debt finance. Second, less reliance on external finance is an important signal of business sustainability.

Table 7. Determination of Capital Structure and Transition Effect

\begin{tabular}{|c|c|c|c|c|c|}
\hline & & & & Model 1 & Model 2 \\
\hline \multicolumn{4}{|l|}{ Constant } & $\begin{array}{c}15.3104 \\
(5.0092) * * *\end{array}$ & $\begin{array}{c}-16.7684 \\
(5.3223) * * *\end{array}$ \\
\hline \multicolumn{4}{|c|}{ Debt ratio $i,(t-1)$} & $\begin{array}{c}0.5286 \\
(0.0091)^{* * *}\end{array}$ & $\begin{array}{c}0.5233 \\
(0.0091)^{* * *}\end{array}$ \\
\hline \multicolumn{4}{|c|}{ Firm characteristics ${ }_{i,(t-1)}$} & Yes & Yes \\
\hline \multicolumn{4}{|c|}{ Year dummies } & Yes & Yes \\
\hline \multicolumn{4}{|l|}{ Firm age $_{i, t}$} & No & Yes \\
\hline \multicolumn{6}{|c|}{ Interaction terms } \\
\hline Stage & Rejuvenator $_{i, t}$ & Stayer $_{i, t}$ & Developer $i, t$ & & \\
\hline Birth $_{i, t}$ & Yes & & & $\begin{array}{c}-3.7626 \\
(0.6628)^{* * *}\end{array}$ & $\begin{array}{c}-3.8378 \\
(0.6615)^{* * *}\end{array}$ \\
\hline Growth $_{i, t}$ & Yes & & & $\begin{array}{c}-5.1953 \\
(0.6741)^{* * *}\end{array}$ & $\begin{array}{c}-5.2873 \\
(0.6729)^{* * *}\end{array}$ \\
\hline Growth $_{i, t}$ & & Yes & & $\begin{array}{c}-3.8660 \\
(0.6703)^{* * * *}\end{array}$ & $\begin{array}{c}-3.8547 \\
(0.6691)^{* * *}\end{array}$ \\
\hline Growth $_{i, t}$ & & & Yes & $\begin{array}{c}-2.4882 \\
(0.7745)^{* * *}\end{array}$ & $\begin{array}{c}-2.5039 \\
(0.7734)^{* * *}\end{array}$ \\
\hline Mature $_{i, t}$ & Yes & & & $\begin{array}{c}-6.2369 \\
(0.7961)^{* * *}\end{array}$ & $\begin{array}{c}-6.2546 \\
(0.7943)^{* * *}\end{array}$ \\
\hline Mature $_{i, t}$ & & Yes & & $\begin{array}{c}-6.2018 \\
(0.6768)^{* * *}\end{array}$ & $\begin{array}{c}-6.3202 \\
(0.6757)^{* * *}\end{array}$ \\
\hline Mature $_{i, t}$ & & & Yes & $\begin{array}{c}-5.0079 \\
(0.6612)^{* * *}\end{array}$ & $\begin{array}{c}-5.0447 \\
(0.6598)^{* * *}\end{array}$ \\
\hline Revivali,t $_{i}$ & Yes & & & $\begin{array}{c}-6.5334 \\
(1.3396)^{* * *}\end{array}$ & $\begin{array}{c}-6.3740 \\
(1.3463)^{* * *}\end{array}$ \\
\hline Revival $_{i, t}$ & & Yes & & $\begin{array}{c}-6.4741 \\
(1.0391)^{* * * *}\end{array}$ & $\begin{array}{c}-6.4823 \\
(1.0368)^{* * * *}\end{array}$ \\
\hline Revival $_{i, t}$ & & & Yes & $\begin{array}{c}-6.8710 \\
(0.7516)^{* * *}\end{array}$ & $\begin{array}{c}-6.9208 \\
(0.7500)^{* * *}\end{array}$ \\
\hline Decline $_{i, t}$ & & Yes & & $\begin{array}{c}-4.6300 \\
(1.1946)^{* * *}\end{array}$ & $\begin{array}{c}-4.6206 \\
(1.1918)^{* * *}\end{array}$ \\
\hline Decline $_{i, t}$ & & & Yes & $\begin{array}{c}-4.7540 \\
(0.8309) * * * \\
\end{array}$ & $\begin{array}{c}-4.7138 \\
(0.8305)^{* * *} \\
\end{array}$ \\
\hline Number of & bservations & & & 8842 & 8826 \\
\hline$F$-test & & & & $179.26^{* * *}$ & $168.11 * * *$ \\
\hline
\end{tabular}


Notes: According to Equation (4), the coefficient of Debtratio $i(t-1)$ is $(1-\lambda)$ and it is a measure of capital structure adjustment speed, $\lambda$. Standard errors are reported in parentheses.***, ** and $*$ represent the statistical significance levels of 1,5 and 10 percent, respectively.

\section{Figure 1. Effects of Transition on Capital Structure}

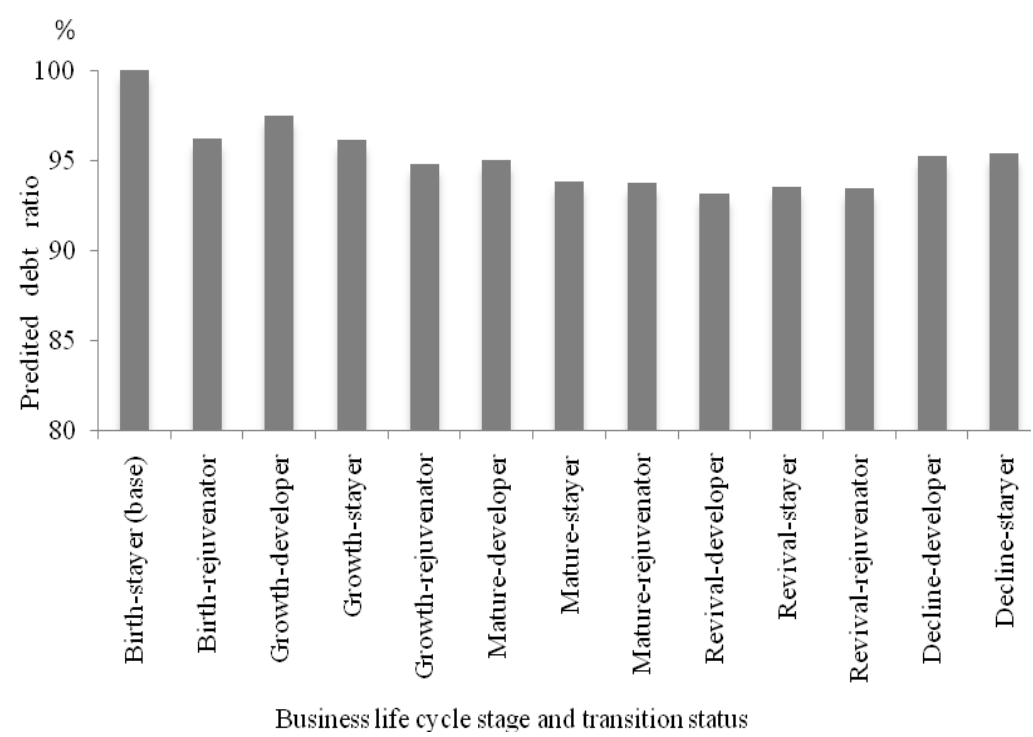

Notes: This figure reports the relative predicted debt ratio for each sub-group sample. We classified the total samples into 13 sub-groups according to its life cycle stage (birth, growth, mature, revival and decline) and transition status (rejuvenator, stayer and developer) at year $t$. We use birth-stayer as the base group. For the debt ratio in other sub-groups, we report the percentage of the absolute value of the debt ratio ( 1 - (absolute percentages value lower than the base group)).

\section{Robustness Check}

As a robustness check, we recode life cycle stages using a categorical variable $\operatorname{stage}_{i, t}$, where stage is coded as 1 if a sample firm $i$ is in the birth stage, 2 in the growth stage, 3 in the mature stage, 4 in the revival stage and 5 in the decline stage at year $t$. We use the squared value of the stage to examine the non-monotonic effect,, and the results are reported in Table 8. Table 8 confirms the reported results above. First, life cycle stages measured by cash flow patterns shed more light on capital structure than firm age, and firm age does not affect business capital structure decisions (as shown in Model 2, Table 5) at a statistically significant level. Second, the debt ratio presents a U-shape along the business life cycle and firms in earlier (birth to growth) stages or decline stages have higher debt ratios. The turning point is at the revival stage (3.93, calculated from Table 8). Third, the average capital structure adjustment speed is approximately 47 percent for all samples and this is the same as the speed estimated in earlier models (see Table 5).

Table 8. Determination of Capital Structure: Fixed Effect Estimation

\begin{tabular}{lc}
\hline & Model \\
\hline Constant & -18.2521 \\
& $(4.9611)^{* * * *}$ \\
Debt ratio $_{i,(t-1)}$ & 0.5284 \\
Stage $_{i, t}$ & $(0.0091)^{* * *}$ \\
& -2.6621 \\
Stage $_{i, t}$ & $(0.4747)^{* * *}$ \\
& 0.3391 \\
& $(0.0845)^{* * *}$
\end{tabular}




\begin{tabular}{lc} 
Firm Characteristics $i,(t-1)$ & Yes \\
Year dummies & Yes \\
\hline Number of observations & 8842 \\
$F$-test & $266.64^{* * *}$ \\
Adjusted $R^{2}$ & 0.292 \\
Hausman $\chi^{2}$ & $3546.23^{* * *}$ \\
\hline
\end{tabular}

Notes: The dependent variable is the total debt ratio in year $t$. Independent variables include lagged firm level characteristics, such as profitability, size, tangibility, growth, tax and life cycle stages. Variable stage is categorical and coded as 1 if a sample firm is in the birth stage, 2 if in the growth stage, 3 if in the mature stage, 4 if in the revival stage and 5 if in the decline stage. The definitions of other variables are available from Table 2 and the empirical model is derived from Equation (4). According to Equation (4), the coefficient of Debtratio $i(t-1)$ is $(1-\lambda)$ and it is a measure of capital structure adjustment speed, $\lambda$. Standard errors are reported in parentheses. $* * *, * *$ and $*$ represent statistical significance levels of 1,5 and 10 percent, respectively.

\section{Conclusions}

In the present paper, we collect firm-level information from Chinese public manufacturing firms between 1999 and 2011 to investigate the determination of their capital structure and the impacts of the business life cycle on capital structure. As well as firm age, we consider a business life cycle measure newly-developed by Dickinson (2011): cash flow patterns. We find that cash flow patterns have a stronger impact than firm age on capital structure. We also identify the important role of the transition between life cycle stages on capital structure, which has not been studied previously. Our panel data allow us to examine the dynamics of capital structure over time and we find that Chinese public manufacturing companies adjust their debt ratio at different speeds when they are in different life cycle stages.

Our research has important implications for policy-makers. It calls for the wellbalancing between products and capital markets, to improve the sustainability of Chinese public firms. This is especially important for firms in their earlier (e.g. birth) and later (e.g. decline) business life cycle stages, which have greater reliance on external finance in the capital market. There are two main benefits of improving the availability of external finance for such firms. First, with better access to external finance, firms in the birth stage have a higher chance of surviving. Second, this provides firms at later stages the chance to rejuvenate themselves and offers the potential for further development.

\section{References}

Adizes, Ichak, 1979, "Organizational passages-Diagnosing and treating lifecycle problems of organizations," Organizational Dynamics, Vol. 8, No. 1, pp. 3-25.

Adizes, Ichak, 1996, "The 10 stages of corporate life cycles," Inc., Vol. 18, No. 14, pp. 95-7.

Adizes, Ichak, 2004, Managing Corporate Life Cycle, 2nd editon, Santa Barbara, CA: The Adizes Institute Publishing.

Amit, Raphael and Paul J. H. Schoemaker, 1993, "Strategic assets and organizational rent," Strategic Management Journal, Vol. 14, No. 1, pp. 33-46.

Bellone, Flora, Patrick Musso, Lionel Nesta and Michel Quéré, 2008, "Market selection along the firm life cycle," Industrial and Corporate Change, Vol. 17, No. 4, pp. 753-77.

Bender, Ruth and Keith Ward, 1993, Corporate Financial Strategy, Oxford: ButterworthHeinemann. 
Berger, Allen N. and Gregory F. Udell, 1998, "The economics of small business finance: The roles of private equity and debt market in the financial growth cycle," Journal of Banking and Finance, Vol. 22, No. 6-8, pp. 613-73.

Black, Ervin L., 1998, "Life-cycle impacts on the incremental value relevance of earnings and cash flows measures," Journal of Financial Statement Analysis, Vol. 4, No. 1, pp. 4056.

Bulan, Laarni and Zhipeng Yan, 2009, “The pecking order of financing in the firm's life cycle," Banking and Finance Letters, Vol. 1, No. 3, pp. 129-40.

Byoun, Soku, 2008, "How and when do firms adjust their capital structures toward targets?" The Journal of Finance, Vol. 63, No. 6, pp. 3069-96.

De Angelo, Harry, Linda De Angelo and René M. Stulz, 2006, "Dividend policy and the earned contributed capital mix: A test of the life-cycle theory," Journal of Finance Economics, Vol. 81, No. 2, pp. 227-54.

Deloof, Marc and Woutervan Overfelt, 2008, "Were modern capital structure theories valid in Belgium before World War I?" Journal of Business Finance and Accounting, Vol. 35, No. 3-4, pp. 491-515.

Dewaelheyns, Nico and van Hulle Cynthia, 2010, "Internal capital markets and capital structure: Bank versus internal debt," European Financial Management, Vol. 16, No. 3, pp. 345-73.

Dickinson, Victoria, 2011, "Cash flow patterns as a proxy for firm life cycle," Accounting Review, Vol. 86, No. 6, pp.1964-94.

Drobetz, Wolfgang and Gabrielle Wanzeried, 2006, "What determines the speed of adjustment to the target capital structure?" Applied Financial Economics, Vol. 16, No. 13, pp. 941-58.

Elasyed, Khaled and David Paton, 2009, "The impact of financial performance on environmental policy: Does firm lifecycle matter?" Business Strategy and the Environment, Vol. 18, No. 6, pp. 397-413.

Fama, Eugene F. and Kenneth R. French, 2002, "Testing tradeoff and pecking order predictions about dividends and debt," The Review of Finance Studies, Vol. 15, No. 1, pp. $1-33$.

Fama, Eugene F. and Kenneth R. French, 2005, "Financing decisions: Who issues stock?" Journal of Financial Economics, Vol. 76, No. 3, pp. 549-82.

Fei, Fei, Ana-Maria Fuertes and Elena Kalotychou, 2012, "Credit rating migration risk and business cycles," Journal of Business Finance and Accounting, Vol. 39, No. 1-2, pp. 22963.

Fluck, Zsuzsanna, 2000, "Capital structure decisions in small and large firms: A life-time cycle theory of financing," New York University Working Paper No. FIN-99-069, New York University Stern School of Business, Waltham.

Frielinghaus, A., B. Mostert and C. Firer, 2005, "Capital structure and the firm's life stage," South African Journal of Business Management, Vol. 36, No. 4, pp. 9-18.

Hamilton, Robert T. and Mark A. Fox, 1998, "The financing preferences of small firm owners," International Journal of Entrepreneurial Behaviour and Research, Vol. 4, No. 3, pp. 239-48.

Hovakimian, Armen and Guangzhong Li, 2011, "In search of conclusive evidence: How to test for adjustment to target capital structure," Journal of Corporate Finance, Vol. 17, No. 1, pp. 33-44.

Huang, Rongbing and Jay Ritter, 2009, "Testing theories of capital structure and estimating the speed of adjustment," Journal of Financial and Quantitative Analysis, Vol. 44, No. 2, pp. 237-71.

Jovanovic, Boyan, 1982, "Selection and the evolution of industry," Econometrica, Vol. 50, No. 3, pp. 649-70. 
Kallunki, Juha-Pekka and Hanna Silvola, 2008, "The effect of organizational life cycle stage on the use of activity-based costing," Management Accounting Research, Vol. 19, No. 1, pp. 62-79.

Khan, Khan and Ross L. Watts, 2009, "Estimation and empirical properties of a firm-year measure of accounting conservatism," Journal of Accounting and Economics, Vol. 48, No. 2-3, pp. 132-50.

Kim, Moshe, Eirik Guard Kristiansen and Bent Vale, 2012, "Life-cycle patterns of interest rate markups in small firm finance," Scandinavian Journal of Economics, Vol. 114, No. 2, pp. 629-57.

La Rocca, Maurizio, Tiziana La Rocca and Alfio Cariola, 2011, "Capital structure decisions during a firm's life cycle," Small Business Economics, Vol. 37, No. 1, pp. 107-30.

Lemmon, Michael L. and Jaime F. Zender, 2010, "Debt capacity and tests of capital structure theories," Journal of Financial and Quantitative Analysis, Vol. 45, No. 5, pp. 1161-87.

Levie, Jonathan and Benyamin B. Lichtenstein, 2010, A terminal assessment of stages theory: Introducing a dynamic states approach to entrepreneurship, Entrepreneurship Theory and Practice, Vol. 34, No. 2, pp. 317-50.

Liang, Chiung-Ju, Ying-Li Lin and Tzu-Tsang Huang, 2011, "Does multi-dimensional ownership structure matter in firm performance? A dynamic firm's life cycle perspective," International Journal of Business and Finance Research, Vol. 5, No. 2, pp. 1-19.

Lin, Szu-Hsien, You-Jie Chen, Ai-Chi Hsu, Ya-Chiu Liu, Hung-Chih Wang, 2012, "Foreign direct investment behaviour: Problemistic or slack search," African Journal of Business Management, Vol. 6, No. 28, pp. 8250-60.

Lippit, Gordon L. and Warren H. Schmidt, 1967, "Crises in a developing organization," Harvard Business Review, Vol. 45, No. 6, pp. 102-12.

Marshall, Jeffrey and Ellen M. Heffes, 2004, "Smaller firms most vulnerable to problems," Financial Executive, Vol. 20, No. 7, p.11.

Merchant, Kenneth A., 1997, Modern Management Control Systems: Text and Cases, New Jersey: Prentice Hall.

Michaelas, Nicos, Francis Chittenden and Panikkos Poutziouris, 1999, "Financial policy and capital structure choice in UK SMEs: Empirical evidence from company panel data," Small Business Economics, Vol. 12, No. 2, pp. 113-30.

Miller, Danny and Peter H. Friesen, 1984, "A longitudinal study of the corporate life cycle," Management Science, Vol. 30, No. 10, pp. 1161-83.

Myers, Stewart C., 1984, “Capital structure puzzle," Journal of Finance, Vol. 39, No. 3, pp. 575-92.

Pfaffermayr, Michael, Matthias Stöckl and Hannes Winner, 2013, "Capital structure, corporate taxation and firm age," Fiscal Studies, Vol. 34, No. 1, pp. 109-35.

Qian, Yanmin, Yao Tian and Tony S. Wirjanto, 2009, "Do Chinese publicly listed companies adjust their capital structure toward a target level?" China Economic Review, Vol. 20, No. 4, pp. 662-76.

Rajan, Raghuram G. and Luigi Zingales, 1995, "What do we know about capital structure? Some evidence from international data," Journal of Finance, Vol. 50, No. 5, pp. 1421-60.

Sakai, Koji, Iichiro Uesugi and Tsutomu Watanabe, 2010, "Firm age and the evolution of borrowing costs: Evidence from Japanese small firms," Journal of Banking and Finance, Vol. 34, No. 8, pp. 1970-81.

Thanatawee, Yordying, 2011, "Life-cycle theory and free cash flow hypothesis: Evidence from dividend policy in Thailand," International Journal of Financial Research, Vol. 2, No. 2, pp. 52-60.

Verreynne, Martie-Louise and Denny Meyer, 2010, "Small business strategy and the industry life cycle,” Small Business Economics, Vol. 35, No. 4, pp. 399-416.

Warr, Richard S., William B. Elliott, Johanna Koëter-Kant and Özde Öztekin, 2012, "Equity mispricing and leverage adjustment costs," Journal of Finance and Quantitative Analysis, 
Vol. 47, No. 3, pp. 589-616. 